Jerzy Sojka

Chrześcijańska Akademia Teologiczna w Warszawie

\title{
Czym jest sobór dla Kościoła? Perspektywa ewangelicka
}

Charakterystyczny dla ewangelickiej teologii i życia kościelnego pluralizm powoduje, że dopisek przy tytułowym pytaniu: ,perspektywa ewangelicka", domaga się już na wstępie doprecyzowania, co będzie przedmiotem prezentacji. Niniejszy artykuł skupi się na jednej z dwóch głównych tradycji wywodzących się z reformacji XVI wieku, która znalazła swoją kontynuację w Kościołach określanych mianem ewangelickich, a mianowicie na tradycji reformacji wittenberskiej związanej z osobą Marcina Lutra. Dlatego też w pierwszej części zostaną zaprezentowane wypowiedzi lidera wittenberskiego ruchu reformacyjnego na temat problematyki soborowej ${ }^{1}$. Część druga uzupełni ten obraz o analizę fundamentów tożsamości luterańskiej, którymi są XVI-wieczne wyznania wiary zgromadzone w Księdze zgody, zwane księgami wyznaniowymi². Część ostatnia będzie miała

${ }^{1}$ Dzieła Lutra cytowane są za edycją: D. Martin Luthers Werke. Kritische Gesamtausgabe, Weimar 1883-2009, według schematu: WA tom, strona; oraz za D. Martin Luthers Werke. Kritische Gesamtausgabe. Abteilung 4: Briefwechsel, Weimar 1930-1985, według schematu WA Br tom, strona.

${ }^{2}$ Luterańskie księgi wyznaniowe cytowane są za edycją: Die Bekenntnisschriften der Evangelisch-Lutherischen Kirche. Vollständige Neuedition, red. I. Dingel i in., Göttingen 
charakter podsumowujący. Zestawienie reformacyjnej wizji nurtu wittenberskiego z problemem soboru (synodu) zostanie w niej jednak uzupełnione przykładami ciał synodalnych funkcjonujących we współczesnej praktyce luterańskiej w perspektywie globalnej na przykładzie Światowej Federacji Luterańskiej - Wspólnoty Kościołów, oraz lokalnej na przykładzie Kościoła Ewangelicko-Augsburskiego w Rzeczypospolitej Polskiej.

\section{Pisma Marcina Lutra}

Refleksję Marcina Lutra nad rolą soboru w Kościele można z perspektywy historycznej podzielić na dwa etapy. Pierwsza jej część przypada na lata 1518-1520, kiedy to kształtuje się jego program reformy Kościoła, a jednocześnie jego postulaty, w których domaga się reform w Kościele, spotykają się z oporem kościelnych autorytetów, a debata raz po raz kierowana jest na kwestię pojmowania roli tych ostatnich. Drugi etap, o wiele bardziej usystematyzowanej (co nie znaczy, że w pełni systematycznej!) refleksji, to druga połowa lat 30. Wypowiedzi Lutra z tego okresu związane są z oczekiwaniem na zwołanie soboru (i ewentualnym udziale w nim protestantów), który ostatecznie rozpocznie obrady w Trydencie w 1545 roku.

Pierwszy ze wspomnianych etapów refleksji Lutra, który rozpoczął się bezpośrednio po jego wystąpieniu przeciw praktyce odpustowej, znanym jako „95 tez przeciw odpustom”, z 31 października 1517 roku, został skonfrontowany z problematyką autorytetu w Kościele, a co za tym idzie, także kwestią pojmowania roli soboru. Juź pierwsza odpowiedź, jaka trafiła do Lutra z Rzymu, przygotowana przez teologa domu papieskiego Silvestra Mazzoliniego z Priero, zwanego Prierasem, nie tyle zajmowała się kwestią nadużyć

2014 [dalej: BSELK] oraz za: Die Bekenntnisschriften der Evangelisch-Lutherischen Kirche. Vollständige Neuedition. Qellen und Materialen, t. 1, red. I. Dingel i in., Göttingen 2014 [dalej: BSELK-QM1]. Odwołania do ich tłumaczeń polskich odnoszą się do edycji: Księgi Wyznaniowe Kościoła Luterańskiego, Bielsko-Biała 2011 [dalej: KWKL]. 
podniesionych przez Lutra w jego tezach, ile sprzeciwiała się podważaniu kościelnych autorytetów: papieża i soborów. Orzeczenia o charakterze kościelnego autorytetu były dla Prierasa podstawą do odrzucenia tez Lutra. Prieras odwoływał się do nieomylności całego Kościoła. Ta nieomylność przysługuje też prawdziwemu soborowi, jeśli ten wypowiada się w sprawach, które są w jego mocy, by zrozumieć prawdę. W czasie procesu poszukiwania prawdy mogą pojawiać się omyłki, jednak dzięki działaniu Ducha Świętego ostateczna decyzja jest nieomylna. Dalsza argumentacja Prierasa dotyczyła także nieomylności papieskiej ${ }^{3}$. Takie stwierdzenia doprowadziły Lutra do przekonania, że zarówno sobory, jak i papież mogą się mylić, czemu dał wyraz po raz pierwszy w odpowiedzi na pismo Prierasa ${ }^{4}$.

Wątpliwości dotyczące roli soborów nie przeszkodziły Lutrowi odwołać się do soboru po tym, jak doszło do przesłuchania go przed kardynałem Kajetanem (Thomas de Vio) w Augsburgu w październiku 1518 roku. Była to druga z apelacji Lutra po tym przesłuchaniu. Pierwszą jeszcze w październiku skierował do papieża Leona X. Drugą, już po powrocie do Wittenbergi w listopadzie, skierował do soboru. W apelacji odwołał się do rozstrzygnięć Soboru w Konstancji (1414-1418) głoszących, że właściwie zwołany, reprezentujący cały Kościół katolicki sobór stoi ponad papieżem ${ }^{5}$, jednocześnie wskazując, że papież takiej apelacji do soboru nie może zakazać, bo stoi to poza jego kompetencjami. Polemizując ze stanowiskiem rzymskim wobec odpustów, jakie było w trakcie trwającego sporu wobec niego reprezentowane, domaga się, by przyszły sobór rozpatrzył tę kontrowersję $e^{6}$.

Po raz kolejny z kwestią autorytetu soboru, i to na przykładzie Soboru w Konstancji, na który powoływał się w swojej apelacji, Luter

\footnotetext{
${ }^{3}$ Por. B. Lohse, Luthers Theologie in ihrer historischen Entwicklung und in ihrem systematischen Zusammenhang, Göttingen 1995, s. 124n.

${ }^{4}$ Por. WA 1, 656; zob. B. Lohse, Luthers Theologie..., dz. cyt., s. 126.

${ }^{5}$ Por. Sobór w Konstancji (1414-1418), Dekret „Haec sancta”, [w:] Dokumenty soborów powszechnych, t. 3, układ i oprac. A. Baron, H. Pietras, Kraków 2003, s. 46-51.

${ }^{6}$ Por. WA 2, 37n.
} 
spotkał się w kolejnym roku w czasie tzw. dysputy lipskiej. W toku polemicznego starcia z Johannesem Eckiem do głosu doszedł spór o potępienie myśli czeskiego reformatora Jana Husa i spalenie go właśnie na Soborze w Konstancji w 1415 roku. Problem wyciągnął Eck, dążąc do oskarżenia Lutra o herezję husycką. Swoją odpowiedź tak relacjonował Luter w liście do swojego przyjaciela Georga Spalatina: „W końcu dyskutowaliśmy także na temat autorytetu soboru. Uznałem publicznie, że niektóre artykuły zostały niesłusznie potępione [przez Sobór w Konstancji], artykuły, których jasno i prosto nauczali Paweł, Augustyn, a nawet sam Chrystus. Wtedy ta żmija spuchła, wyolbrzymiła moje przestępstwo i niemalże oszalała w swoich pochlebstwach wobec publiczności w Lipsku. Następnie dowiodłem słowami samego soboru, że nie wszystkie potępione przezeń artykuły były rzeczywiście heretyckie i błędne"7.

Powyższe stwierdzenie, że Sobór w Konstancji mylił się w sprawie Husa, nie przeszkadzało Lutrowi przywołać w tezach sformułowanych przed debatą autorytetu „najbardziej świętego ze wszystkich soborów" - I Soboru w Nicei, jako argumentu na rzecz tego, że Kościół rzymski nie jest nadrzędny wobec wszystkich innych. Wzmianka o Soborze w Nicei pojawia się jako egzemplifikacja trwającej jedenaście wieków historii Kościoła, w której nie pojawiały się tego typu roszczenia papieskie ${ }^{8}$.

Ten etap soborowej refleksji reformatora zamyka w pewnym sensie jedno z trzech tzw. pism programowych, które opublikował w drugiej połowie 1520 roku. Straciwszy nadzieję na możliwość reformy Kościoła z udziałem papiestwa, Luter w piśmie Do chrześcijańskiej szlachty niemieckiego narodu o ulepszeniu chrześcijańskiego stanu zwraca się do drugiego kluczowego czynnika władzy w ówczesnej Rzeszy, a mianowicie władzy świeckiej. Pismo to we wstępie zawiera zdefiniowanie i obalenie trzech murów, którymi papiestwo zabezpieczyło swoją pozycję przed wszelkimi reformami. Dwa pierwsze

\footnotetext{
WA Br $1,422$.

${ }^{8}$ Por. WA 2, 161.
} 
odnoszą się do nadrzędności stanu duchownego nad świeckim oraz rezerwacji wykładu Pisma Świętego dla papiestwa. Luter obala je, odwołując się do powszechnego kapłaństwa wszystkich ochrzczonych oraz interpretacji tekstu z Ewangelii św. Mateusza (Mt 16, 19), zgodnie z którą klucze przekazane zostały całemu zborowi, a nie jedynie personalnie Piotrowi ${ }^{9}$. Trzeci mur miał ubezpieczać dwa poprzednie, a polegał na tym, że „Jeśli im [stronie papieskiej] się grozi soborem, wtedy się wykręcają, iż nikt nie może zwoływać soboru, jak tylko papież"10. Luter rozpoczyna obalenie tego muru od przywołania tekstu z Ewangelii św. Mateusza (Mt 18, 15): „A jeśliby zgrzeszył przeciwko tobie brat twój, idź, upomnij go sam na sam: jeśliby zaś nie usłuchał, przybierz sobie jeszcze jednego albo dwóch. A jeśliby ich nie usłuchał, powiedz zborowi. A jeśliby zboru nie usłuchał, niech ci będzie jako poganin". W świetle tego tekstu Luter interpretuje sobór jako zbór, przed którym winien stanąć papież postępujący wbrew Pismu Świętemu. Dlatego też zgromadzenie takiego zboru-soboru nie może być zarezerwowane dla papieża. Rezerwacja taka, zdaniem Lutra, wynika tylko z ustaw papieskich, a nie z Pisma Świętego, które poświadcza, że sobór apostolski (Dz 15) nie został zwołany osobiście przez Piotra, ale przez wszystkich apostołów. Podobnie rzecz się miała z I Soborem w Nicei, który został zwołany przez cesarza Konstantyna. Jeśliby koniecznym było, by papież je zwoływał, to oba wymienione sobory miałyby charakter kacerski. Stąd też w zaistniałej sytuacji obowiązek zwołania takiego reformatorskiego soboru spada na władzę świecką, która jako współchrześcijanie i współkapłani (na mocy powszechnego kapłaństwa) zobowiązana jest do troski o chrześcijaństwo i ratowania go. Protesty papieskie zaś, jeśliby miały prowadzić do przeszkodzenia wolnemu, a więc nie zwołanemu pod władzą papieską, soborowi,

\footnotetext{
${ }^{9}$ Por. WA 6, 406-412; tłum. polskie: Do chrześcijańskiej szlachty niemieckiego narodu o ulepszenie chrześcijańskiego stanu (1520), tłum. J. Lasota, „Z Problemów Reformacji”, t. 6 (1993), s. 154-158.

${ }^{10}$ WA 6, 406; tłum. polskie: M. Luter, Do chrześcijańskiej szlachty..., dz. cyt., s. 154.
} 
należy zignorować: „Nie mają też oni [zwolennicy papieża] mocy przeszkodzić soborowi lub go według swego upodobania ograbić, zobowiązać i pozbawić go swobody. A jeżeli to czynią, to są oni naprawdę społecznością antychrysta i diabła i od Chrystusa nie mają nic, jak tylko nazwę"11.

W omawianym piśmie Luter formułuje również propozycje tematów, jakimi powinien zająć się sobór ${ }^{12}$, a także zajmuje się całą listą kwestii odnoszących się do reform wewnątrz Rzeszy Niemieckiej oraz jej stosunków z papiestwem, zaczerpniętych z Gravamina der deutsche nation ${ }^{13}$. W tej części pisma pojawiają się postulaty, by sobór zajął się zniesieniem celibatu duchownych ${ }^{14}$, a także krytyka decyzji soborów średniowiecznych. Powtarza się przy tym znany z Lipska motyw krytyki decyzji Soboru w Konstancji w sprawie Husa i postulatów husyckich. Luter nie wdaje się w ostateczne rozstrzygnięcie prawdziwości tez husyckich (choć pisze: „mój rozum u niego jeszcze nic błędnego nie znalazł"15), swoją krytykę zaś koncentruje na złamaniu listu żelaznego danego Husowi przed soborem i konsekwencjach, jakie to przyniosło, w postaci wojen husyckich w Czechach ${ }^{16}$. W kontekście postulatu redukcji personelu kurialnego, jako przykład oderwania od wiary dworu papieskiego, Luter podaje decyzje Soboru Laterańskiego V odnośnie do nieśmiertelności duszy, a także wymogu dochowywania modlitw dla zachowania

${ }^{11}$ WA 6, 415; tłum. polskie: M. Luter, Do chrześcijańskiej szlachty..., dz. cyt., s. 160. Por. WA 6, 412-415; tłum. polskie: M. Luter, Do chrześcijańskiej szlachty..., dz.cyt., s. $158-160$.

${ }^{12}$ Szczegółowa analiza zob. T. Kaufmann, An den christlichen Adel deutscher Nation von des christlichen Standes Besserung, Tübingen 2013, s. 141-211.

${ }^{13}$ Por. J. Wahlmann, Kirchengeschichte Deutschlands seit der Reformation, wyd. 7, Tübingen 2012, s. 29.

${ }^{14}$ Por. WA 6, 441; tłum. polskie: M. Luter, Do chrześcijańskiej szlachty..., dz.cyt., s. 175.

${ }^{15}$ WA 6, 454; tłum. polskie: M. Luter, Do chrześcijańskiej szlachty..., dz. cyt., s. 183.

${ }^{16}$ Por. WA 6, 454-457; tłum. polskie: M. Luter, Do chrześcijańskiej szlachty..., dz. cyt., s. $182-184$. 
beneficjów ${ }^{17}$. Z drugiej strony, ponownie, rozstrzygnięcia I Soboru w Nicei są dla Lutra wzorcowe. Na zaproponowaną tam procedurę powoływania biskupów powołuje się w kontekście zarówno postulatów zmian w nadawaniu urzędów biskupich, jak i propozycji rozwiązania kryzysu czeskiego powstałego w wyniku błędów na Soborze w Konstancji ${ }^{18}$.

W przedstawionym wyżej okresie wypowiedzi Lutra na temat roli soborów w Kościele mają raczej charakter przygodny. W wypowiedziach reformatora pojawiają się echa stanowiska koncyliarystów, które stawiało sobór nad papieżem. Widać to zarówno w apelacji do soboru, jak i w postulacie zwołania soboru dla przeprowadzenia reformy Kościoła. W związku z tym, że sobór ten miał być zwołany przeciw papieżowi, było konieczne, by starożytnym zwyczajem zwołała go władza świecka. Ten postulat „wolnego soboru”, tj. soboru nie pod władzą papieską, będzie powtarzał się także w latach 30 . w kontekście ówczesnych sporów o zwołanie soboru. W wypowiedziach Lutra pojawia się także inny wątek jego późniejszej refleksji, który ma dużo bardziej zasadnicze znaczenie. Chodzi o nieabsolutyzowanie autorytetu soboru w Kościele, co wiąże się z przyznaniem, że także sobór może się mylić. Tym samym, mimo odwołania do soboru czy przekonania o nadrzędności soboru nad papieżem, trudno Lutra uznać za koncyliarystę ${ }^{19}$. Warto przy tym zwrócić uwagę, że na tym etapie wskazania dotyczące omylności soborów odnoszą się do rozstrzygnięć soborów doby średniowiecza uznawanych

${ }^{17}$ Por. WA 6, 432n; tłum. polskie: M. Luter, Do chrześcijańskiej szlachty..., dz. cyt., s. 170. Kontekst tej krytyki Lutra naświetla: T. Kaufmann, An den christlichen Adel deutscher Nation..., dz. cyt., s. 239-241.

${ }^{18}$ Por. WA 6, 429, 455; tłum. polskie: M. Luter, Do chrześcijańskiej szlachty..., dz. cyt., s. $167,183$.

${ }^{19}$ Por. ocenę Lohsego (Luthers Theologie..., dz. cyt., s. 133n); inaczej w kontekście wypowiedzi o papiestwie z Artykułów szmalkaldzkich ocenia nastawienie Lutra Gunther Wenz, określając go mianem ,antypapalistycznego koncyliarysty”. Zob. G. Wenz, Theologie der Bekenntnisschriften der evangelisch-lutherischen Kirche. Eine historische und systematische Einführung in das Konkordienbuch, t. 2, Berlin 1998, s. 418 n. 
za powszechne w Kościele zachodnim ${ }^{20}$. Rozstrzygnięcia I Soboru w Nicei stanowią zaś przykład pozytywny.

Zanim przejdziemy do przedstawienia wypowiedzi Lutra z drugiego okresu, w którym intensywnie zajmował się problematyką soborową, warto wskazać jeszcze na jedną z jego wypowiedzi z lat 20. Pochodzi ona z pisma Daß eine christliche Versammlung oder Gemeinde Recht und Macht habe, alle Lehre zu beurteilen und Lehrer zu berufen, Einund Abzusetzen: Grund und Ursache aus der Schrift [Zgromadzenie albo chrześcijański zbór ma prawo i władzę, by oceniać wszelkie nauki i powoływać, mianować i odwoływać nauczycieli - podstawa i powód z Pisma] z 1523 roku. Już sam tytuł definiuje dwa główne zagadnienia tego pisma: 1 . prawo zboru do oceny nauki; 2. prawo zboru do powoływania pełniących urząd kościelny. Jest ono odpowiedzią Lutra na kierowane do niego przez zreformowany zbór w Leisnig prośby o przedstawienie pochodzącego z Pisma Świętego uzasadnienia dla zalecanej w czasie jego wizyty w Leisnig w 1522 roku praktyki powoływania przez zbór osób na urząd kościelny ${ }^{21}$. Zajmując się prawem zboru do oceny nauki chrześcijańskiej, Luter wskazuje, że zgodnie z wypowiedziami Chrystusa, Chrystus powierzył prawo do oceny nauki nie biskupom, nauczycielom czy soborom, ale swoim owcom. Przywołany fragment z Ewangelii św. Jana (J 10, 4n. 9) komentuje następująco: „Widać tu jasno, kto ma prawo nauczać doktryny: biskupi, papieże, uczeni i każdy inny ma władzę nauczania, ale to owce mają osądzać, czy nauczają oni głosu [tj. słów] Chrystusa, czy głosu obcych. Moi drodzy, cóż mogą powiedzieć przeciwko temu te bańki na wodzie, szurający stopami «Sobory, sobory! Trzeba słuchać

${ }^{20}$ Wśród treści odrzuconych znalazła się także zawarta na przykład w piśmie De captivitate Babylonica ecclesaie praeludium [0 niewoli babilońskiej Kościoła] krytyka transsubstancjacji i udzielania komunii pod jedną postacią. Zob: WA 6, 507-512. Por. Sobór w Konstancji (1414-1418), Potępienie komunii pod dwiema postaciami, przywróconej wśród Czechów przez Jakubka ze Střibra, [w:] DSP III, s. 108-111.

${ }^{21}$ Por. M. Luther. That a Christian Assembly or Congregation Has The Right And Power To Judge All Teaching And To Call, Appoint, And Dismiss Teachers, Established And Proven By Scripture. Introduction, [w:] Luther's works, t. 39, Philadelphia 1970, s. 301-304. 
uczonych, biskupów, tłumu; trzeba patrzyć na stare porządki i zwyczaje»? Czy sądzicie, że Słowo Boże powinno ustąpić przed Waszym starym porządkiem, zwyczajem i biskupami? Nigdy! Dlatego pozwalamy biskupom i soborom decydować i ustanawiać co chcą; gdy Słowo Boże jest po naszej stronie, my - a nie oni - będziemy sądzić, co jest właściwe, a co nie, a oni będą się musieli nam poddać i być posłuszni naszemu słowu"22.

Druga połowa lat 30. to w Rzeszy Niemieckiej oczekiwanie na zwołanie soboru ${ }^{23}$. W 1535 roku nowo wybrany papież Paweł III wysłał do Rzeszy nuncjusza Pietro Paolo Vergerio, który miał przygotować grunt pod przyszłe zwołanie soboru. W listopadzie tego samego roku odwiedził on także Wittenbergę i spotkał się z Lutrem² ${ }^{24}$ W 1536 roku ogłoszona została przez papieża Pawła III bulla zapraszająca na sobór do Mantui, który ostatecznie nie doszedł do skutku. Te wydarzenia powodowały, że strona reformacyjna musiała nie tylko podjąć decyzję, czy brać udział w soborze, a jeśli tak, to przygotować się do udziału w nim, ale także zająć się problemem soboru szerzej. Odpowiedzią Lutra na pierwsze zagadnienie, przygotowaną na zlecenie elektora saskiego mimo dystansu samego reformatora oraz innych przedstawicieli stanów protestanckich do brania udziału w soborze zwołanym przez papieża, są Artykuły szmalkaldzkie z 1536/1537 roku, które znalazły się później w zbiorach luterańskich ksiąg wyznaniowych i wraz z nimi zostaną omówione niżej25. Odpowiedzią zaś na drugą kwestię są dwa pisma Lutra. Pierwszym z nich, powstałym w kontekście wizyty nuncjusza i zaproszeń na sobór z lat 1535-1536, są tezy Disputation de potestatae concilii [Dysputacji o władzy soborów],

\footnotetext{
${ }^{22}$ WA 11, 409n.

${ }^{23}$ Odnośnie do problemów ze zwołaniem soboru zob. K. Schatz, Sobory powszechne. Punkty zwrotne w historii Kościoła, tłum. J. Zakrzewski, Kraków 2001, s. 161-170.

${ }^{24}$ Por. M. Brecht, Martin Luther. Die Erhaltung der Kirche 1532-1546, Stuttgart 1987, s. $174-178$.

${ }^{25}$ Zob. W. Niemczyk, Historia powstania „Artykułów szmalkaldzkich” $i$ „Traktatu o władzy i prymacie papieża", [w:] KWKL, s. 329-333; G. Wenz, Theologie der Bekenntnisschriften..., dz.cyt., t. 1, Berlin 1996, s. 513-541.
} 
datowanej na 10 października 1536 roku. Drugim z nich jest traktat Von Konziliis und Kirchen [O soborach i Kościele] z 1539 roku, który powstał, kiedy już wiadomo było, że papież Paweł III porzucił ideę zwołania soboru.

Pierwsze z wyżej wspomnianych pism to trzydzieści tez dysputy akademickiej. Luter rozpoczyna w nich od stwierdzenia, że po władzy (autorytecie) Chrystusa nie ma autorytetu (władzy) równego apostołom i prorokom, wszystkie inne władze (autorytety) kościelne są ich uczniami. Wynika to z faktu, że apostołowie otrzymali osobiście obietnice Ducha Świętego. Dlatego też oni wyłącznie mogę być nazwani „fundamentami Kościoła” (fundamentum Ecclesiae) i mogą ustanawiać artykuły wiary. Ich następcy nie mają tej osobistej obietnicy Ducha Świętego, stąd też nie zyskali prawa do tego, by realizować wszystkie zadania, jakie powierzono apostołom. Odnosi się to szczególnie do kwestii nowych artykułów wiary, których nie mają prawa ustanawiać, a jedynie mają prawo podążać za apostolską nauką oraz ustanowieniami i je zachowywać. Tezę o różnicy między apostołami i ich następcami Luter argumentuje, odwołując się do 1 Listu św. Piotra (1 P 4, 11) i 2 Listu św. Piotra (1 P 1, 21). W oparciu o te teksty wskazuje, że nikt nie zwiastuje Słowa Bożego z własnej woli. Jest to dzieło Ducha Świętego. Bez inspiracji Ducha Świętego każdy wykład Pisma Świętego jest tylko własnym wykładem człowieka. Już na wstępie swoich rozważań Luter podkreślał, że obietnicę Ducha Świętego otrzymali osobiście apostołowie, a nie ich następcy. Dlatego ci, którzy przyszli po apostołach, zobowiązani są do kontynuacji ich apostolskiego fundamentu, w przeciwnym razie należy ich uznać za heretyków i antychrystów ${ }^{26}$.

Idąc dalej w swoich rozważaniach, w omawianej dyspucie Luter stwierdza, że zgromadzenia biskupów albo sobory mogą się mylić, tak samo jak wszyscy inni ludzie, czy to w odniesieniu do swoich urzędów, czy też spraw prywatnych. Zdarzały się sytuacje, w których sobór się nie mylił. Nie wynikało to jednak z istoty tego

\footnotetext{
${ }^{26}$ Por. WA 39 I, 184n (tezy 1-11).
} 
zgromadzenia, ale była to zasługa jakiegoś świętego męża spośród biskupów, albo też zasługa Kościoła ${ }^{27}$. Wynika to z faktu, że żadna obietnica Boża nie wiąże Ducha Świętego ze zgromadzeniem biskupów bądź soborem. Stąd roszczenie soborów do bycia uznanym za zgromadzone w Duchu Świętym Luter uznaje za fałszywe i widzi w tym przejaw pychy, a wręcz bluźnierstwo. Zgromadzenie w Duchu Świętym jest możliwe jedynie, jeśli kontynuuje ono apostolski fundament i nie wypowiada własnych myśli, ale działa zgodnie z wiarą. Reformator przyznaje przy tym, że sobór reprezentuje Kościół powszechny, przy czym relacja soboru i Kościoła przedstawia się jak relacja namalowanego obrazu człowieka do samego człowieka, sobór jest zatem jedynie przedstawieniem prawdziwego Kościoła. Sobór może stać się prawdziwym Kościołem, a nie jedynie jego reprezentacją, jeżeli działa zgodnie z apostolską wiarą. Działanie takie jednak nie należy do istoty soboru, czego dowodzą przykłady historyczne. Z taką konstatacją na temat istoty soboru wiąże się to, że nikt nie jest zobowiązany do automatycznego posłuszeństwa rozstrzygnięciom soborów. Powinien najpierw według Pisma Świętego ocenić, czy w danym wypadku sobór działa jak prawdziwy Kościół. Te decyzje, które nie przeszły pozytywnie takiej weryfikacji, można pominąć. Wyraz takiej logiki reformator dostrzega w wypowiedziach wskazujących, że mając dobre podstawy w Piśmie Świętym, nawet jeden człowiek może przeciwstawić się soborowi. Jednak o ile było to możliwe w czasach I Soboru Nicejskiego, gdzie jeden biskup Pafnucy przekonał sobór i zyskał sobie tym powszechne uznanie, to w czasach bliższych Lutrowi takie osoby były potępione i palone, jak choćby na Soborze w Konstancji. To ostatnie jest aluzją do losu Jana Husa i Hieronima z Pragi ${ }^{28}$.

${ }^{27}$ Jako przykład podany jest tutaj biskup Pafnucy, który miał zapobiec błędnej decyzji Soboru w Nicei. Jak podaje edytor WA (WA 39 I, 186, przyp. 1), chodzi o biskupa Pafnucego z Górnej Tebaidy, który zgodnie z przekazem Sokratesa Scholastyka miał zablokować decyzję soboru o wprowadzeniu celibatu duchownych. Por. Sokrates Scholastyk, Historia Kościoła, tłum. S. J. Kozikowski, Warszawa 1986, s. 101n.

${ }^{28}$ Por. WA 39 I, 185-187 (tezy 12-30). 
Drugie z pism tego okresu - O soborach i Kościele - to znacznie obszerniejszy traktat. Jest on świadectwem obszernych studiów historycznych Lutra poświęconych soborom i jest uznawany za jego ostateczne stanowisko z lat 30. XVI wieku w sprawie wysiłków na rzecz powołania soboru ${ }^{29}$. Pismo rozpoczyna się od stwierdzenia, że papież zwleka ze zwołaniem soboru, a przy tym podejmuje kroki, by nie był to sobór wolny, a więc niezależny od jego władzy i zdolny go krytycznie ocenićc ${ }^{30}$. Luter podkreśla przy tym, że starożytne sobory zwoływała władza świecka ${ }^{31}$. Dotyczy to szczególnie czterech głównych soborów, tj. Soboru w Nicei (325), w Konstantynopolu (381), w Efezie (431) oraz w Chalcedonie (451). Powołuje się tu na to, że zajmują one szczególną pozycję „prawie we wszystkich księgach"32, przy czym zaznacza, że niektóre z pozostałych „uważa za dobre”33. Te właśnie sobory oraz sobór apostolski w Jerozolimie opisany w Dziejach Apostolskich (Dz 15) staną się przedmiotem pogłębionej analizy w części drugiej pisma ${ }^{34}$.

Część podsumowującą otwiera stwierdzenie, że wszystkie omówione sobory zwoływane były, by bronić istniejących prawd wiary, nie zaś po to, by ustanawiać nowe. Wprowadzane przez nich nowe rozwiązania dotyczące dyscypliny czy organizacji Kościoła odnoszą się do rzeczy przemijających i zbędnych, których regulowanie jest wymagane nie tylko na soborach, ale także w codziennym życiu parafii i szkół. Stąd też według Lutra zadaniem soborów nie jest ustanawianie nowych artykułów wiary czy dobrych uczynków, ale obrona dawnej wiary i dobrych uczynków. Tak czyniły omówione sobory, broniąc prawd wiary dotyczących boskości

\footnotetext{
${ }^{29}$ Por. M. Brecht, Martin Luther..., dz. cyt., s. 194-198.

${ }^{30}$ Por. WA 50, 509-511; tłum. polskie: M. Luter, O soborach i Kościołach, tłum. J. Gryniakow, „Z Problemów Reformacji”, t. 6 (1993), s. 193.

${ }^{31}$ Por. WA 50, 522; tłum. polskie: M. Luter, O soborach i Kościołach, dz. cyt., s. 199.

32 WA 50, 522; tłum. polskie: M. Luter, O soborach i Kościołach, dz. cyt., s. 199.

${ }^{33}$ WA 50, 543; tłum. polskie: M. Luter, O soborach i Kościołach, dz. cyt., s. 210.

${ }^{34}$ Por. WA 50, 547-606; tłum. polskie: M. Luter, O soborach i Kościołach, dz. cyt., s. 212-244.
} 
poszczególnych osób Trójcy Świętej czy też Bogoczłowieczeństwa Chrystusa. Ustanawianie nowych artykułów wiary czy uczynków z pewnością nie jest dziełem Ducha Świętego, gdyż takie działanie realizuje się „bez i poza Pismem Świętym”, takie zaś sobory są soborami Kajfasza, Piłata i Heroda ${ }^{36}$.

Następnie reformator przechodzi do sformułowania dziesięciu tez odpowiadających na pytanie o istotę i zadanie soboru. Pierwsze cztery pary z nich sformułowane są według schematu: teza pierwsza zabrania ustanawiania nowości przez sobór, teza druga wzywa, by takim ustanowieniom przeciwdziałać. Kolejne pary tez odnoszą się w tym schemacie do ustanawiania: 1 . nowych artykułów wiary; 2. nowych dobrych uczynków ponad te, o których mówi Pismo Święte; 3. nowych ceremonii, których dochowanie obciąża sumienia lub ich zaniechanie grozi grzechem śmiertelnym; 4. nowych praw odnośnie do porządku świeckiego. Teza dziewiąta zabrania tworzenia takich statutów, które prowadzą do tyranii, jak na przykład ustanawiających nieograniczoną władzę biskupów. Teza dziesiąta zaś stwierdza, że sobór ma prawo ustanawiać nowe ceremonie, ale tylko jeśli spełnią one następujące dwa warunki: 1 . nie będą wzmacniać tyranii biskupów; 2. będą pożyteczne dla ludu w kształtowaniu karności i dobrego prowadzenia życia ${ }^{37}$.

Podsumowując zadania soborów, Luter zaznacza, że świadomie ogranicza je do działalności sądzącej. Ich zwoływanie dotyczy przypadków, kiedy naprawy wymaga jakaś szczególna sytuacja w Kościele. W normalnym zaś funkcjonowaniu Kościoła prerogatywy osądzania i oceny nauki oraz obrony istniejących artykułów wiary przysługują nauczycielom, proboszczom i biskupom, każdemu w zakresie ich odpowiedzialności. To, czy sobór postrzega tak swoje działanie, pozwala ocenić, czy jest prawdziwy, czy fałszywy.

\footnotetext{
${ }^{35}$ WA 50, 606; tłum. polskie: M. Luter, O soborach i Kościołach, dz. cyt., s. 244.

${ }^{36}$ Por. WA 50, 606; tłum. polskie: M. Luter, O soborach $i$ Kościołach, dz.cyt., s. 244.

${ }^{37}$ Por. WA 50, 607n., 613n; tłum. polskie: M. Luter, O soborach i Kościołach, dz. cyt., s. 245,248 .
} 
Luter przestrzega też przed traktowaniem soborów jako podstawy chrześcijaństwa, gdyż jest nią wyłącznie Pismo Święte. Zauważa też, że sobory powinny ograniczyć się jedynie do spraw wiary ${ }^{38}$.

$\mathrm{Na}$ tej podstawie reformator formułuje także swoje aktualne postulaty dotyczące zapowiedzianego soboru. Powinien on zostać zwołany, by bronić artykułu wiary o zbawieniu jedynie z łaski przez wiarę. Co za tym idzie, powinien osądzić papieża, który godzi swym nauczaniem i roszczeniami $\mathrm{w}$ ten artykuł. Jest to sprawa na tyle istotna, że godna jest zwołania soboru, przy czym musi się tym zajać władza świecka, tak jak to miało miejsce w przypadku czterech głównych starożytnych soborów. Luter proponuje też, by sobór nie gromadził wszystkich biskupów, opatów, nauczycieli itd., ale by z każdego kraju wydelegowano osoby gruntownie znające Pismo Święte i oddane zachowaniu wiary chrześcijańskiej, wśród nich także osoby świeckie. Obrady powinny zaś się skupić na głównym zadaniu, tak by nie czynić $\mathrm{z}$ soboru forum załatwiania różnorodnych zatargów. Na koniec Luter wyraża swój pesymizm co do możliwości zwołania takiego soboru, przy czym podkreśla, że tylko taki sobór będzie miał sens. Jeśli taki sobór nie dojdzie do skutku, to na takich samych zasadach mógłby się odbyć prowincjonalny synod dla ziem niemieckich ${ }^{39}$.

Stanowisko Lutra $\mathrm{z}$ lat 30. na temat soboru jest bardziej uporządkowane niż to, które wyłania się z polemik prowadzonych do roku 1520. Jego zasadnicze rysy są jednak rozwinięciem tez, jakie już wtedy formułował. Luter nie widzi w soborze najwyższego autorytetu w Kościele, gdyż także sobór podporządkowany jest autorytetowi Słowa Bożego i Pisma Świętego i powinien wydawać osąd na ich podstawie. Co więcej, nie zakłada, że sobór sam w sobie, dzięki szczególnemu wsparciu Ducha Świętego, jest nieomylny. Jego zadanie

\footnotetext{
${ }^{38}$ Por. WA 50, 614-619; tłum. polskie: M. Luter, O soborach i Kościołach, dz. cyt., s. $248-251$.

${ }^{39}$ Por. WA 50, 619-624; tłum. polskie: M. Luter, O soborach i Kościołach, dz. cyt., s. 251-254.
} 
ogranicza ostatecznie do bycia szczególnego rodzaju sądem, który ma stać na straży istniejących artykułów wiary, mających pochodzenie apostolskie. To zadanie dzieli on z proboszczami, biskupami i nauczycielami. Szczególna pozycja soboru wynika jedynie z faktu, że jest on zwoływany przy okazji wyjątkowego zagrożenia dla Kościoła, kiedy konieczna jest obrona fundamentów wiary. Luter dostrzega przy tym, że sobory wypowiadały się na temat spraw doczesnych w istnieniu Kościoła. Nie można jednak tym rozstrzygnięciom przypisać atrybutu nieomylności czy powszechnej obowiązywalności, choć istnienie takowych rozstrzygnięć może być pożyteczne. Sam jednak optuje za tym, by sobory skupiły się na obronie zagrożonych prawd wiary. W ich składzie widzi nie tylko biskupów czy przedstawicieli innych instancji władzy kościelnej, ale również osoby, także świeckie, biegłe w Piśmie Świętym i gotowe bronić wiary.

\section{Luterańskie księgi wyznaniowe}

Luterańskie księgi wyznaniowe nigdzie szerzej nie zajmują się kwestią odpowiedzi na pytanie, czym jest sobór. Pewne wnioski można w tej materii wyciągnąć jedynie ze wstępu do Artykułów szmalkaldzkich oraz pojedynczych wzmianek z Traktatu o władzy i prymacie papieża autorstwa Filipa Melanchtona. Wynika to z faktu, że oba pisma powstały w kontekście zapowiedzi zwołania soboru z drugiej połowy lat 30 . W pozostałych pismach wyznaniowych (z wyjątkiem Lutrowych katechizmów) prześledzić jednak można odwołania do soborów, w których autorzy poszczególnych ksiąg bądź to powołują się na ich nauczania, jako artykuły wiary podzielane przez zreformowane Kościoły, bądź też odrzucają jakieś elementy rozstrzygnięć soborowych.

W Wyznaniu augsburskim z 1530 roku najważniejsze odniesienie do uchwał I Soboru Nicejskiego znalazło się w artykule I O Bogu, w którym strona reformacyjna deklaruje expressis verbis uznanie rozstrzygnięć tego soboru (oraz Soboru Konstantynopolitańskiego I) w odniesieniu do nauczania o Trójcy Świętej, poświadczając to 
ujęciem wśród poglądów odrzuconych także arianizmu ${ }^{40}$. Potwierdza to również włączenie do Księgi zgody, a więc zbioru luterańskich ksiąg wyznaniowych, Wyznania nicejsko-konstantynopolitańskiego ${ }^{41}$. W tle artykułu III O Synu Bożym stoją rozstrzygnięcia soborów w Efezie oraz Chalcedonie, a także określenia dotyczące Ducha Świętego zaczerpnięte z symbolu nicejsko-konstantynopolitańskiego ${ }^{42}$. W Wyznaniu augsburskim pojawia się także argument z kanonów Soboru Nicejskiego, który ma poświadczać w artykule XXIV O mszy, że starożytny Kościół nie praktykował codziennej Eucharystii ${ }^{43}$.

Obrona Wyznania augsburskiego powtarza ten schemat, potwierdzając ustalenia artykułu I i III Wyznania augsburskiego, tym razem expressis verbis podkreślając $\mathrm{w}$ drugim $\mathrm{z}$ tych artykułów zgodność z symbolem nicejsko-konstantynopolitańskim ${ }^{44}$. Oprócz tego rozstrzygnięcia soborowe są dla Filipa Melanchtona, autora Obrony..., argumentem w różnorodnych kwestiach w innych artykułach. Bez precyzowania, o który sobór chodzi, na zgodność praktyki ewangelickiej z dawnymi kanonami soborowymi powołuje się przy okazji omawiania kwestii zadośćuczynieńn ${ }^{45}$, także w odniesieniu do praktyki spowiedniej, widząc w nich działania o charakterze dyscyplinarnym ${ }^{46}$, zrywanie małżeństw duchownych i celibatu ${ }^{47}$. Konkretnie wymienione są tylko ustalenia Soboru w Nicei dotyczące daty Wielkanocy w kontekście wolności co do zwyczajów w Kościele ${ }^{48}$. W Obronie... znalazło się także bezpośrednie odrzucenie ustaleń soborowych.

\footnotetext{
${ }^{40}$ Por. Wyznanie augsburskie [dalej: CA], art. I, [w:] BSELK, s. 92-95 (KWKL, s. 143).

${ }^{41}$ Por. Wyznanie nicejsko-konstantynopolitańskie, [w:] BSELK, s. 49n (KWKL, s. 529).

${ }^{42}$ Por. CA, art. III, [W:] BSELK, s. 96-99 (KWKL, s. 143n).

${ }^{43}$ Por. CA, art. XXIV, [w:] BSELK, s. 146n (KWKL, s. 153). Por. Sobór Nicejski I (325), Kanon XVIII, [w:] DSP I, s. 42-45.

${ }^{44}$ Por. Obrona wyznania augsburskiego [dalej: ACA], art. I, III, [w:] BSELK-QM1, s. 428, 434 (KWKL, s. 167, 173).

${ }^{45}$ Por. ACA, art. XII, 122, [w:] BSELK-QM1, s. 517n (KWKL, s. 252n).

${ }^{46}$ Por. ACA, art. XII, 167, [w:] BSELK-QM1, s. 525 (KWKL, s. 260).

${ }^{47}$ Por. ACA, art. XXIII, 3.6.23n, [w:] BSELK-QM1, s. 550n.553 (KWKL, s. 287n.290).

${ }^{48}$ Por. ACA, art. VII i VIII, 42, [w:] BSELK-QM1, s. 498 (KWKL, s. 232).
} 
Chodzi o konstytucję Soboru Laterańskiego IV pt. Omnis utriusque, głoszącą obowiązek spowiedzi minimum raz w roku ${ }^{49}$.

Podobne odniesienia znajdziemy także w Artykułach szmalkaldzkich Lutra. Część pierwsza, w której omówione są artykuły, co do których nie ma sporu między stroną ewangelicką a papieską, dotyczy wyłącznie dorobku pierwszych czterech soborów powszechnych, tj. dogmatu trynitarnego i chrystologicznego ${ }^{50}$. W części drugiej, w której zdefiniowano artykuły, od których nie można odstąpić, oraz w części trzeciej, zawierającej artykuły do dyskusji, znajdują się odwołania do rozstrzygnięć soborowych stanowiące argumenty

${ }^{49}$ Por. ACA, art. XI, 1.3, [w:] BSELK-QM1, s. 499n (KWKL, s. 234); Sobór Laterański IV, Konstytucja o nakazie spowiedzi i związanej z nia tajemnicy oraz o obowiązk przyjmowania Komunii świętej przynajmniej w czasie Paschy, [w:] DSP II, s. 258-261.

${ }^{50}$ Por. Artykuły szmalkaldzkie [dalej: AS], cz. I, [w:] BSELK, s. 726-728 (KWKL, s. 337n). Wyznanie wiary Marcina Lutra z 1528 roku głosi: „Po pierwsze wierzę w doniosły artykuł o Bożym Majestacie. Wierzę, że Ojciec, Syn i Duch Święty - trzy różniące się pomiędzy sobą osoby - są rzeczywiście jednym, istotnym, prawdziwym Bogiem, Stworzycielem nieba i ziemi i wszystkich rzeczy (wbrew arianom, macedonianom, sabelianom i tym podobnym herezjom), jak to jest dotąd wyznawane zarówno w Kościele rzymskim, jak i na całym świecie w kościołach chrześcijańskich. Po drugie wierzę i wiem, iż Pismo Święte nas poucza, że Syn Boży, stał się prawdziwym człowiekiem, poczętym z Ducha Świętego, bez udziału mężczyzny, i narodził się z czystej, świętej Marii - prawdziwej, naturalnej matki, jak to święty Łukasz wyraźnie opisał (Łk 1,26.38) i prorocy zwiastowali. A więc to nie Ojciec ani Duch Święty stał się człowiekiem, jak niektórzy heretycy nauczają. Wierzę również, iż Bóg Syn przyjął nie tylko ciało bez duszy, jak niektórzy heretycy twierdzą, lecz także i duszę, tj. całe, pełne człowieczeństwo. Jako prawowity potomek był przyobiecany Abrahamowi i Dawidowi, i jako naturalny syn narodził się z Marii. Pod każdym względem był prawdziwym człowiekiem, tym się jednak różnił, że przyszedł bez grzechu, z Dziewicy przez Ducha Świętego (Hbr 2, 17; 4,15). Wierzę, że ten człowiek jest prawdziwie Bogiem, i że jako jedna, wieczna nierozerwalna z Bogiem osoba stał się człowiekiem, oraz że Maria, święta Dziewica, jest prawdziwą i rzeczywistą matką nie tylko człowieka Chrystusa, jak uczą nestorianie, lecz Syna Bożego, jak mówi Łukasz ( Łk 1, 35): „To, co się narodzi, będzie święte i będzie nazwane Synem Bożym". Jest to mój i wszystkich ludzi Pan, Jezus Chrystus, jedyny, prawdziwy, naturalny syn Boga i Marii, prawdziwy Bóg i człowiek" (WA 26, 500-502); tłum. polskie: Wyznanie o Wieczerzy Pańskiej, tłum. J. Pośpiech, Bielsko-Biała 2014, s. 191n. 
zarówno na rzecz stawianych przez reformatora tez, jak i odrzuconych przez niego praktyk. W tej pierwszej kategorii znalazła się argumentacja z IV artykułu części II 0 papiestwie, w którym sobory są ogólnie przywoływane na potwierdzenie tego, że papież nie jest jedynie biskupem zboru w Rzymie, a co za tym idzie, inni biskupi są mu równi jako jego bracia ${ }^{51}$. Luter odwołuje się też do działań Soboru w Konstancji, który złożył papieży z urzędu, by zakończyć schizmę zachodnią, w czym reformator widzi przykład ewentualnego funkcjonowania papiestwa jako obieralnej głowy chrześcijaństwa dla zabezpieczenia przeciw sekciarzom i heretykom. Szybko jednak dodaje, że takie pojmowanie papiestwa kłóci się z istotą ówczesnego pojmowania papiestwa rzymskiego ${ }^{52}$.W drugiej grupie mieszczą się wypowiedzi zawarte w artykule VI części III O Sakramencie Ołtarza, w którym odrzucono ustalenia expressis verbis Soboru w Konstancji dotyczące nauki o konkomitacji oraz, bez wspominania Soboru Laterańskiego IV, odrzucono także doktrynę transsubstancjacji53.

Ze względu na ich kontekst w Artykułach szmalkaldzkich znalazła się także refleksja na temat roli soboru. Zawarta została jednak nie w częściach głównych pisma, ale w przedmowie. Zaczyna się ona od omówienia okoliczności zwołania soboru. Luter krytykuje przy tym zabiegi kurii rzymskiej prowadzące do uniknięcia jego zwołania. Domaga się także zwołania wolnego, chrześcijańskiego soboru. Do jego zadań miałoby należeć usunięcie zaniedbań w wielu parafiach, takich jak na przykład fakt, że pozostają one opuszczone ${ }^{54}$. Spod potrzeby naprawy reformator wyłącza zreformowane Kościoły i zbory, ze względu na to, że „nasze bowiem Kościoły, dzięki łasce Bożej, są oświecone, pouczone i utwierdzone w czystym Słowie Bożym i w należytym korzystaniu z sakramentów, i w znajomości powołań, i prawych uczynków tak, iż nam soboru nie trzeba i sobór nie może nam

\footnotetext{
${ }^{51}$ Por. AS, cz. II, art. IV, 1, [w:] BSELK, s. 738-740 (KWKL, s. 342n).

${ }^{52}$ Por. AS, cz. II, art. IV, 7, [w:] BSELK, s. 742 (KWKL, s. 343).

${ }^{53}$ Por. AS, cz. III, art. VI, 2.5, [w:] BSELK, s. 766-768 (KWKL, s. 339n).

${ }^{54}$ Innym przykładem jest reforma mszy, o której mowa w AS, cz. II, art. II, 10, BSELK, s. 732 (KWKL, s. 342n).
} 
ukazać nic lepszego i doskonalszego" 55 . Oprócz tego widzi wśród zadań soboru istotne kwestie natury politycznej, np. spory między książętami i stanami, a także różnego rodzaju nadużycia w życiu społecznym (lichwa, pijaństwo itd.). Jeśliby sobór skupił się na tych kwestiach, to „nie byłoby trzeba śmiesznych, na żart zakrawających pogawędek o długich szatach, odróżniających zawojach, o tonsurach i wygoleniach, o szerokich wstęgach czy sprzączkach, o infułach biskupich czy kardynalskich, o kapeluszach, czapkach, laskach i tym podobnych głupstwach" ${ }^{56}$. Sobór powinien się zajmować najpierw rzeczami istotnymi ze sfery kościelnej i polityczno-społecznej, a dopiero jeśli starczy mu czasu, zajmować się tak nieistotnymi kwestiami jak reformy zwyczajów w Kościele dotyczących pokarmów, strojów itd. Przyglądając się zadaniom i ich hierarchii, jakie Luter stawia przed soborem, można wywnioskować, że sobór jest tutaj dla niego instancją naprawczą Kościoła i społeczeństwa. Naprawianie to zaś powinno się odbywać według normy Słowa Bożego ${ }^{57}$. Te konkluzje współgrają z tezami głoszonymi w jego pismach z lat 30. omówionymi powyżej.

Kolejne pismo wyznaniowe, które powstało w kontekście przygotowań do soboru z lat 30., to Traktat o władzy i prymacie papieża autorstwa Filipa Melanchtona, który stanowił uzupełnienie Wyznania augsburskiego. Argumenty z rozstrzygnięć soborowych w Nicei służą dla poparcia tez o roszczeniu do prymatu biskupa rzymskiego wynikającego z prawa ludzkiego ${ }^{58}$, odnośnie do procedur wyboru biskupów i braku ich zatwierdzania przez papieża ${ }^{59}$. Melanchton przy okazji nadużyć papieża wypowiada się także na temat relacji papieża i soboru oraz zadań tego ostatniego. Sprzeciwia się stawianiu papieża ponad soborem, widzi w tym papieską ucieczkę przed

\footnotetext{
${ }^{55}$ AS, Przedmowa, 10, [w:] BSELK, s. 722 (KWKL, s. 336).

${ }^{56}$ AS, Przedmowa, 13, [w:] BSELK, s. 722-724 (KWKL, s. 337).

${ }^{57}$ AS, Przedmowa, 13, [w:] BSELK, s. 722-724 (KWKL, s. 335-337).

${ }^{58}$ Por. Traktat o władzy i prymacie papieża, 12.17, [w:] BSELK, s. 800-804 (KWKL, s. 360n).

${ }^{59}$ Por. Traktat o władzy..., dz. cyt., 13, [w:] BSELK, s. 802 (KWKL, s. 360).
} 
osądzeniem jego nauki ${ }^{60}$. Wskazuje także, że orzeczenia soborów to orzeczenia Kościoła, a więc jeśli biskupi nie spełniają swej roli obrońców czystości wiary, także przed błędami papieża, to o zwołanie soboru powinna zatroszczyć się władza świecka. Kościół musi bowiem zachować możliwość rozstrzygania i osądzania na podstawie Słowa Bożego ${ }^{61}$.

Ostatnia z luterańskich ksiąg wyznaniowych - Formuła zgody z 1577 roku - również jedynie odwołuje się do soborów w ramach argumentacji bądź w odniesieniu do poglądów odrzuconych. Korzysta ona szczególnie z dorobku rozstrzygnięć chrystologicznych Efezu i Chalcedonu ${ }^{62}$. W jej zapisach znalazło się także odrzucenie ustaleń Soboru Trydenckiego dotyczących roli dobrych uczynków dla zbawienia ${ }^{63}$.

Ten krótki przegląd nawiązań do soborów w luterańskich księgach wyznaniowych pozwala stwierdzić, że uznają one ustalenia dogmatyczne pierwszych czterech soborów powszechnych. W treści Księgi zgody pojawiają się także odrzucenia ustaleń soborowych, dotyczą one jednak jedynie soborów średniowiecznych oraz Soboru Trydenckiego. Rozstrzygnięcia soborowe pojawiają się też jako argumenty dla obrony określonych reform w Kościele. Jeśli chodzi o samą rolę soboru, to z niewielkich wzmianek obecnych w Artykułach szmalkaldzkich oraz w Traktacie o władzy i prymacie papieża wyłania się obraz soboru jako instytucji, która pełni naprawczą rolę w Kościele. Normą tej naprawy jest treść Słowa Bożego. Na jej przeszkodzie nie może stawać papież, stawiając się nad soborem, a Kościół powinien zachować prawo do korzystania z naprawy soborowej, więc, gdy to konieczne, sobór winna zwołać władza świecka.

${ }^{60}$ Por. Traktat o władzy..., dz. cyt., 40.49n, [w:] BSELK, s. 816.818-820 (KWKL, s. 363365).

${ }^{61}$ Por. Traktat o władzy..., dz. cyt., 56, [w:] BSELK, s. 822 (KWKL, s. 365).

${ }^{62}$ Por. Formuła zgody, Epitome, art. VII, 18, [w:] BSELK, s. 1273-1275 (KWKL, s. 417); Formuła zgody, Solida declaratio, art. VIII, 18.46.59.62.76, [w:] BSELK, s. 1513, 1525, 1529, 1539 (KWKL, s. 495n., 499, 501n., 504).

${ }^{63}$ Por. Formuła zgody, Solida declaratio, art. IV, 35, [w:] BSELK, s. 1429 (KWKL, s. 467). 


\section{Zamiast zakończenia: luterańska współczesność}

Przedstawione wyżej rozważania reformacyjne pozwalają wskazać na zasadnicze cechy soboru czy też synodu partykularnego, w refleksji reformacji wittenberskiej. Zasadniczym jego zadaniem jest stanie na straży artykułów wiary. Sobory (synody) są więc swoistymi sądami broniącymi wiary Kościoła w sytuacjach jej nadzwyczajnego zagrożenia. W obliczu takiego zagrożenia sobór reprezentuje Kościół i jest miejscem, w którym należy dokonać oceny i naprawy nauki. Kiedy zaś nie ma takiego zagrożenia, to prawo do oceny nauki jest realizowane w ramach poszczególnych zborów za pośrednictwem osób, którym powierzono odpowiedni urząd (proboszcza, biskupa, nauczyciela). Autorytet soboru nie jest wiązany ze szczególną obietnicą obecności Ducha Świętego w tym zgromadzeniu, ale z wiernością Słowu Bożemu. Tym samym autorytet soboru podporządkowany jest autorytetowi Słowa Bożego zawartego w Piśmie Świętym. Taka redukcjonistyczna tendencja w pojmowaniu soboru (synodu) nie przeszkadza widzieć w nim instytucji, której podporządkowane powinny być inne instytucje kościelne (np. papiestwo), a także właściwego forum dla debaty o reformie w Kościele. Granice podporządkowania i reform wyznacza jednak autorytet Słowa Bożego. To pozwalało reformatorom z jednej strony uznawać i cenić ustalenia soborowe (szczególnie pierwszych czterech soborów ekumenicznych), a z drugiej odrzucać niektóre ustalenia soborów średniowiecznych. W wypowiedziach Lutra dochodzą też do głosu postulaty oddania prerogatywy zwoływania soboru w ręce władzy świeckiej, jako wyraz jej troski o Kościół chrześcijański, a także nie ograniczania składu soboru do biskupów, ale budowania go ze znawców Pisma Świętego, przejętych reformą Kościoła, także świeckich. Pytanie, jak ta wizja jest realizowana we współczesnym luteranizmie?

Patrząc w perspektywie globalnej, luterańskim ciałem o charakterze synodalnym jest Zgromadzenie Ogólne Światowej Federacji Luterańskiej. Co prawda statut tej organizacji nie przyznaje mu wyżej wskazanych reformacyjnych kompetencji synodalnych, tj. prawa do 
osądzania nauki ${ }^{64}$, jednak faktem jest, że to właśnie Zgromadzenie Ogólne powołane jest do formułowania statutu Federacji, który zawiera między innymi podstawę doktrynalną ŚFL ${ }^{65}$. Poza tym prześledzenie historii wypowiedzi Zgromadzeń Ogólnych ŚFL pokazuje, że w konkretnych przypadkach, takich jak zawieszenie Kościołów członkowskich praktykujących apartheid ${ }^{66}$, spełnia ono zadania stania na straży czystości nauki. W tych kategoriach można też odczytywać wysiłki kolejnych Zgromadzeń Ogólnych na rzecz reinterpretacji kluczowych artykułów wiary, jak nauka o usprawiedliwieniu ${ }^{67}$ czy też IV prośba Modlitwy Pańskiej ${ }^{68}$. Takie wypowiedzi Zgromadzenia Ogólnego nabierają znaczenia wraz ze wzrostem świadomości ŚFL o byciu wspólnotą Kościołów ${ }^{69}$. Skład Zgromadzenia

${ }^{64}$ Por. Constitution of The Lutheran World Federation (as adopted by the LWF Eighth Assembly, Curitiba, Brazil, 1990, including amendments adopted by the LWF Ninth Assembly, Hong Kong, 1997 and by the LWF Eleventh Assembly, Stuttgart, 2010), https://www. lutheranworld.org/sites/default/files/Constitution\%20EN\%20final_0.pdf (22.12.2015), art. VII; tłum. polskie: Statut Światowej Federacji Luterańskiej (przyjęty przez VIII Zgromadzenie Ogólne, 1990, Kurytyba, Brazylia, wraz ze zmianami przyjętymi przez IX Zgromadzenie Ogólne 1997, Hong-Kong i XI Zgromadzenie Ogólne 2010, Stuttgart, Niemcy, [w:] J. Sojka, Wieczerza Pańska jako nota ecclesiae w publikacjach Światowej Federacji Luterańskiej, praca doktorska w ChAT, s. 429, art. VII.

${ }^{65}$ Por. Constitution..., art. cyt., art. II i art. XVI, pkt 1; tłum. polskie: Statut..., dz. cyt., s. 427 , art. II i s. 433 , art. XVI, pkt 1.

${ }^{66}$ Por. Erklärung über Südliches Afrika: Konfessionelle Integrität, [w:] „In Christus Hoffnung die Welt" Offizieler Bericht der Siebenten Vollversammlung des Lutherischen Weltbundes. Budapest, Ungarn 22. Juli-5. August 1984, red. C. H. Mau, „LWB-Report” t. 19/20 (1985), s. 187n.

${ }^{67}$ Por. Rechtfertigung heute (Endgültige Fassung des Dokumentes 75), [w:] Offizieller Bericht der Vierten Vollversammlung des Lutherischen Weltbundes, Helsinki, 30. Juli 11. August 1963, Berlin-Hamburg 1965, s. 522-529; Bericht und Verpflichtung der Neunten Vollversammlung des Lutherischen Weltbundes, [w:] Im Christus - zum Zeugnis berufen. Offizieller Bericht der Neunten Vollversammlung des Lutherischen Weltbundes. Hong-Kong 8.-16. Juli 1997, Genf brw., s. 43-62.

${ }^{68}$ Message from the Eleventh Assembly, [w:] Give Us Today Our Daily Bread. Official Report LWF Eleventh Assembly Stuttgart, Germany, 20-27 July 2010, Geneva 2010, s. 41-46.

${ }^{69}$ Zob. J. Sojka, dz. cyt., s. 129-211; Vom Weltbund zur Gemeinschaft, red. J. H. Schjørring i in., Hannower 1997, s. 192-219. 
Ogólnego, w którym zachowano m.in. parytety osób świeckich ${ }^{70}$, odzwierciedla także postulaty Lutra o udziale osób świeckich w działalności synodalnej. Teza o synodalnym charakterze Zgromadzenia Ogólnego ŚFL napotyka na jedno zasadnicze ograniczenie. Orzeczenia Zgromadzenia Ogólnego są wiążące jedynie dla działań Federacji jako organizacji zrzeszającej Kościoły członkowskie, nie zaś dla samych Kościołów członkowskich ŚFL, które w ramach organizacji zachowują pełną autonomię ${ }^{71}$.

W perspektywie krajowej należy stwierdzić, że synody (synod Kościoła oraz synody diecezjalne) stanowią istotny element ustrojowy Kościoła Ewangelicko-Augsburskiego w Rzeczypospolitej Polskiej $^{72}$. Reformacyjnej wizji synodu jako strażnika nauki odpowiada szczególnie jedno z zadań przewidzianych dla synodu Kościoła: „Sprawowanie pieczy nad zachowaniem czystości nauki i nad podniesieniem życia religijno-moralnego w Kościele"73. Zadanie to jest realizowane między innymi poprzez uchwalanie „Zasadniczego Prawa Wewnętrznego” Kościoła ${ }^{74}$, którego „Deklaracja wstępna” zawiera podstawy doktrynalne Kościoła Ewangelicko-Augsburskiego

${ }^{70}$ Por. Resolution regarding LWF principles of inclusivity, [w:] Give Us Today..., dz.cyt., s. $61 \mathrm{n}$.

${ }^{71}$ Por. Constitution..., art. cyt., art. IV; tłum. polskie: Statut..., dz. cyt., s. 428, art. IV.

${ }^{72}$ Ustrój Kościoła Ewangelicko-Augsburskiego w RP od strony prawnej charakteryzuje: Z. Obracaj, Ustrój Kościoła Ewangelicko-Augsburskiego w Rzeczypospolitej Polskiej, „Przegląd Prawa Wyznaniowego” t. 6 (2014), s. 95-166 (na temat roli synodów szczególnie: s. 98-109, 120-130).

${ }^{73}$ Zasadnicze Prawo Wewnętrzne Kościoła Ewangelicko-Augsburskiego w Rzeczypospolitej Polskiej z dnia 26 października 1996 r. z późniejszymi poprawkami dokonanymi na: 3. Sesji X Synodu Kościoła - 18.04.1998 r.; 4. Sesji X Synodu Kościoła - 21.11.1998 r., 5. Sesji X Synodu Kościoła - 10.04.1999 r.; 6. Sesji X Synodu Kościoła - 06.11.1999 r.; 4. Sesji XI Synodu Kościoła26.10.2003 r.; 5. Sesji XI Synodu Kościoła - 18.04.2004 r:; 9. Sesji XI Synodu Kościoła-23.04.2006 r.; 10. Sesji XI Synodu Kościoła - 5.11.2006 r.; 4. Sesji XII Synodu Kościoła - 18.10.2008 r.; 9. Sesji XII Synodu - 9.04.2011 r.; 10. Sesji XII Synodu - 16.10.2011 r.; 2. Sesji XIII Synodu - 27.10.1012r.; 7. Sesji XIII Synodu - 11.04.2015r, http://www.bik.luteranie.pl/files/Prawo/2015-0411ZPW.pdf (22.12.2015), s. 12, §64, pkt 2.

${ }^{74}$ Por. tamże, s. $16, \S 81$. 
w Rzeczypospolitej Polskiej ${ }^{75}$, a także poprzez adaptowanie treści artykułów wiary do bieżących zmian społecznych, związanych szczególnie z wyzwaniami bioetycznymi ${ }^{76}$. Jeżeli chodzi o synod diecezjalny, powierzono mu między innymi rozstrzygnięcia dotyczące życia religijnego diecezji ${ }^{77}$. Należy także odnotować, że synody Kościoła Ewangelicko-Augsburskiego w Rzeczypospolitej Polskiej realizują postulaty obecności świeckich $\mathrm{w}$ ich pracach. W synodzie diecezjalnym zasiadają delegaci świeccy z każdej parafii danej diecezji ${ }^{78}$, w synodzie Kościoła zaś trzydziestu delegatów świeckich wybieranych przez poszczególne synody diecezjalne ${ }^{79}$.

\section{Bibliografia}

Apologia Confessio Augustanae, [w:] BSELK-QM1, s. 391-590; tłum. polskie: Obrona Wyznania Augsburskiego (Apologia Konfesji Augsburskiej), tłum. W. Niemczyk, [w:] KWKL, s. 165-325.

Artikel christlicher Lehre so da hätten pollen aufs Concilium zu Mantua oder wo es sonst worden wäre überantwort werden von unsers Teils wegen und was wir annehmen oder nachgeben kunnten oder nicht etc. Durch Dokt. Martin Luther geschrieben. Anno 1537, [w:] BSELK, s. 718-785; tłum. polskie: Artykuły szmalkaldzkie z 1537, tłum. W. Niemczyk, [w:] KWKL, s. 335-358.

\footnotetext{
75 Por. tamże, s. 1.

${ }^{76}$ Por. Oświadczenie Kościoła Ewangelicko-Augsburskiego w sprawie ochrony życia, http://www.luteranie.pl/o_naszym_kosciele/oswiadczenia_kosciola/w_sprawie_ ochrony_zycia.html (22.12.2015); Oświadczenie Kościoła Ewangelicko-Augsburskiego w RP w sprawie dopuszczalności stosowania metody in vitro, http://www.luteranie.pl/o_ naszym_kosciele/oswiadczenia_kosciola/w_sprawie_dopuszczalnosci_stosowania_ metody_in_vitro.html (22.12.2015); Oświadczenie Kościoła Ewangelicko-Augsburskiego $w R R$ w sprawie transplantacji i dawstwa organów, http://www.luteranie.pl/o_naszym_ kosciele/oswiadczenia_kosciola/w_sprawie_transplantacji_i_dawstwa_organow. html (22.12.2015).

77 Por. Zasadnicze Prawo Wewnętrzne..., dz. cyt., s. 9, § 46, pkt 2.

${ }^{78}$ Por. tamże, s. 9, § 44.

${ }^{79}$ Por. tamże, s. $11 \mathrm{n}, \S 59$, pkt 4.
} 
Bericht und Verpflichtung der Neunten Vollversammlung des Lutherischen Weltbundes, [w:] Im Christus - zum Zeugnis berufen. Offizieller Bericht der Neunten Vollversammlung des Lutherischen Weltbundes. Hong-Kong 8.-16. Juli 1997, Genf brw., s. $43-62$.

Die Augsburgische Konfession. Confessio oder Bekenntnis des Glaubens etlicher Fürsten und Städte uberantwort Kaiserlicher Majestat zu Augsburg Anno 1530. Confessio fidei exhibita invictissimo Imperatori Carolo V. Ceasari Augusto in comitiis Augustae Anno MDXXX, [w:] BSELK, s. 84-225; tłum. polskie: Wyznanie augsburskie (Konfesja Augsburska) z 1530 roku, przeł. z łaciny J. J. Jackowski, [w:] KWKL, s. 143-163; Wyznanie augsburskie (Konfesja Augsburska) z 1530 r. Czesść pierwsza, przeł. z niemieckiego A. Wantuła, BKE ${ }^{1}$, s. 25-45; Przedmowa, [w:] L. Grane, Wyznanie augsburskie. Wprowadzenie w podstawowe myśli Reformacji luterańskiej, Bielsko-Biała 2002, s. 23-27.

Brecht M., Martin Luther. Die Erhaltung der Kirche 1532-1546, Stuttgart 1987.

Constitution of The Lutheran World Federation (as adopted by the LWF Eighth Assembly, Curitiba, Brazil, 1990, including amendments adopted by the LWF Ninth Assembly, Hong Kong, 1997 and by the LWF Eleventh Assembly, Stuttgart, 2010), https://www.lutheranworld.org/sites/default/files/Constitution\%20EN\%20 final_0.pdf (22.12.2015); tłum. polskie: Statut Światowej Federacji Luterańskiej (przyjęty przez VIII Zgromadzenie Ogólne, 1990, Kurytyba, Brazylia, wraz ze zmianami przyjętymi przez IX Zgromadzenie Ogólne 1997, Hong-Kong i XI Zgromadzenie Ogólne 2010, Stuttgart, Niemcy, [w:] J. Sojka, Wieczerza Pańska jako nota ecclesiae w publikacjach Światowej Federacji Luterańskiej, praca doktorska w ChAT, s. 429-433.

De potestates et primatu papae tractatus per theologos Smalcaldiae congregatos conscriptus Anno 1537, [w:] BSELK, s. 796-837; tłum. polskie: Traktat o władzy i prymacie papieża. Napisany przez teologów w Szmalkalden w 1537 roku, tłum. W. Niemczyk, [w:] KWKL, s. 359-369.

Erklärung über Südliches Afrika: Konfessionelle Integrität, [w:] „In Christus Hoffnung die Welt" Offizieler Bericht der Siebenten Vollversammlung des Lutherischen Weltbundes. Budapest, Ungarn 22.Juli - 5. August 1984, red. C. H. Mau, „LWB-Report” t. 19/20 (1985), s. 187-188.

Formula Concordiae, [w:] BSELK, s. 1184-1607; tłum. polskie: Formuła zgody z 1577 roku, tłum. J. Pośpiech, [w:] KWKL, s. 387-528.

Kaufmann T., An den christlichen Adel deutscher Nation von des christlichen Standes Besserung, Tübingen 2013.

Lohse B., Luthers Theologie in ihrer historischen Entwicklung und in ihrem systematischen Zusammenhang, Göttingen 1995. 
Luther M., Ad dialogum Silvestri Prieriatis de potestate papae responsio (1518), [w:] WA 1, 647-686.

Luther M., An der christlichen Adel deutscher Nation von des christliches Standes Besserung (1520), [w:] WA 6, 404-469; tłum. polskie: Do chrześcijańskiej szlachty niemieckiego narodu o ulepszenie chrześcijańskiego stanu (1520), tłum. J. Lasota, „Z Problemów Reformacji” t. 6 (1993), s. 153-192.

Luther M., Appellatio F. M. Luther ad concilium (1518), [w:] WA 2, 36-40.

Luther M., Daß eine christliche Versammlung oder Gemeinde Recht und Macht habe (1523), [w:] WA 11, 408-416.

Luther M., Disputatio de potestate concillii (1536?), [w:] WA 39 I, 184-197.

Luther M., Disputatio et excusatio F. M. Luther adversus criminationes D. Joh. Eccii (1519), [w:] WA 2, 160n.

Luther M., Nr. 187. Luther an Spalatin [Witteneberg] 20. Juli 1519, [w:] WA Br 1, 420-424.

Luther M., Vom Abendmahl Christi, Bekenntnis (1528), [w:] WA 26, 261-506; tłum. polskie: Wyznanie o Wieczerzy Pańskiej, tłum. J. Pośpiech, Bielsko-Biała 2014.

Luther M., Von den Konzilen und der Kirche (1539), [w:] WA 50, 509-653; tłum. polskie: M. Luter, O soborach i Kościołach, tłum. J. Gryniakow, „Z Problemów Reformacji" t. 6 (1993), s. 193-271.

M. Luther. That a Christian Assembly or Congregation Has The Right And Power To Judge All Teaching And To Call, Appoint, And Dismiss Teachers, Established And Proven By Scripture. Introduction, [w:] Luther's works, t. 39, Philadelphia 1970, s. 301-304.

Message from the Eleventh Assembly, [w:] Give Us Today Our Daily Bread. Official Report LWF Eleventh Assembly Stuttgart, Germany, 20-27 July 2010, Geneva 2010, s. 41-46.

Niemczyk W., Historia powstania „Artykułów szmalkaldzkich” i „Traktatu o władzy i prymacie papieża", [w:] KWKL, s. 329-333.

Obracaj Z., Ustrój Kościoła Ewangelicko-Augsburskiego w Rzeczypospolitej Polskiej, „Przegląd Prawa Wyznaniowego” t. 6 (2014), s. 95-166.

Oświadczenie Kościoła Ewangelicko-Augsburskiego w RP w sprawie dopuszczalności stosowania metody in vitro, http://www.luteranie.pl/o_naszym_kosciele/ oswiadczenia_kosciola/w_sprawie_dopuszczalnosci_stosowania_metody_in_ vitro.html (22.12.2015).

Oświadczenie Kościoła Ewangelicko-Augsburskiego w RR w sprawie transplantacji i dawstwa organów, http://www.luteranie.pl/o_naszym_kosciele/oswiadcze nia_kosciola/w_sprawie_transplantacji_i_dawstwa_organow.html (22.12.2015). 
Oświadczenie Kościoła Ewangelicko-Augsburskiego w sprawie ochrony życia, http://www.luteranie.pl/o_naszym_kosciele/oswiadczenia_kosciola/w_spra wie_ochrony_zycia.html (22.12.2015).

Rechtfertigung heute (Endgültige Fassung des Dokumentes 75), [w:] Offizieller Bericht der Vierten Vollversammlung des Lutherischen Weltbundes, Helsinki, 30. Juli11. August 1963, Berlin-Hamburg 1965, s. 522-529.

Resolution regarding LWF principles of inclusivity, [w:] Give Us Today Our Daily Bread. Official Report LWF Eleventh Assembly Stuttgart, Germany, 20-27 July 2010, Geneva 2010, s. 61-62.

Schatz K., Sobory powszechne. Punkty zwrotne w historii Kościoła, tłum. J. Zakrzewski, Kraków 2001.

Sobór Laterański IV, Konstytucja o nakazie spowiedzi i związanej z nią tajemnicy oraz o obowiązu przyjmowania Komunii świętej przynajmniej w czasie Paschy, [w:] DSP II, s. 258-261.

Sobór Nicejski I (325), Kanon XVIII, [w:] DSP I, s. 42-45.

Sobór w Konstancji (1414-1418), Dekret „Haec sancta”, [w:] DSP III, s. 46-51. Sobór w Konstancji (1414-1418), Potępienie komunii pod dwiema postaciami, przywróconej wśród Czechów przez Jakubka ze Stříbra, [w:] DSP III, s. 108-111.

Sokrates Scholastyk, Historia Kościoła, tłum. S. J. Kozikowski, Warszawa 1986. Vom Weltbund zur Gemeinschaft, red. J. H. Schjørring i in., Hannower 1997.

Wahlmann J., Kirchengeschichte Deutschlands seit der Reformation, wyd. 7, Tübingen 2012.

Wenz G., Theologie der Bekenntnisschriften der evangelisch-lutherischen Kirche. Eine historische und systematische Einführung in das Konkordienbuch, t. 1-2, Berlin 1996-1998.

Wyznanie nicejsko-konstantynopolitańskie, [w:] BSELK, s. 49-50 (KWKL, s. 529).

Zasadnicze Prawo Wewnętrzne Kościoła Ewangelicko-Augsburskiego w Rzeczypospolitej Polskiej z dnia 26 października 1996 r. z późniejszymi poprawkami dokonanymi na: 3. Sesji X Synodu Kościoła - 18.04.1998 r.; 4. Sesji X Synodu Kościoła-21.11.1998r., 5. Sesji X Synodu Kościoła-10.04.1999 r.; 6. Sesji X Synodu Kościoła06.11.1999 r.; 4. Sesji XI Synodu Kościoła - 26.10.2003 r.; 5. Sesji XI Synodu Kościoła 18.04.2004 r.; 9. Sesji XI Synodu Kościoła - 23.04.2006 r.; 10. Sesji XI Synodu Kościoła - 5.11.2006 r.; 4. Sesji XII Synodu Kościoła - 18.10.2008 r.; 9. Sesji XII Synodu 9.04.2011 r.; 10. Sesji XII Synodu - 16.10.2011 r.; 2. Sesji XIII Synodu-27.10.1012 r.; 7. Sesji XIII Synodu - 11.04.2015 r., http://www.bik.luteranie.pl/files/Prawo/2015-0411ZPW.pdf (22.12.2015). 


\section{What is Council to the Church? An Evangelical Perspective}

SUMMARY

The article presents the way of understanding a council established within the Wittenberg Reformation, based on the example of Martin Luther's statements and the Lutheran Symbolical Books. The Wittenberg Reformers saw in the council an authority, guarding the articles of faith, but subordinate to the authority of the God's Word. They also did not connect it with a special promise of the Holy Spirit's presence in such an assembly. It allowed them to approach the results of particular councils critically. The articles of faith passed by the first four ecumenical subjects were accepted in a special way. Among the rejected contents were primarily the decisions of medieval councils. The article is concluded by a presentation on how the Reformation's vision of a council (synod) is applied in current practice, on the example of the General Assembly of Lutheran World Federation and the synods of the Evangelical Church of the Augsburg Confession in Poland.

KEYWORDS: council, Martin Luther, lutheran symbolical books, Lutheran World Federation, Evangelical Church of Augsburg Confession in Poland

SŁOWA KLUCZOWE: sobór, Marcin Luter, luterańskie księgi wyznaniowe, Światowa Federacja Luterańska, Kościół Ewangelicko-Augsburski w RP 